\title{
La Réunion Island: A Typical Example of a Basaltic Shield Volcano with Rapid Evolution
}

\author{
Nicolas Villeneuve, Patrick Bachèlery, and Jacobus Kemp
}

\begin{abstract}
La Réunion Island is a volcanic area located in a tropical climate context. Volcanism has built up a $7 \mathrm{~km}$ high cone over the last five million years. For the last two or three million years, magmatic, tectonic and weathering processes have been engaged in a gigantic race to shape the island's morphologies, with dramatic consequences in terms of landforms such as volcanic peaks (the dormant Piton des Neiges and active Piton de la Fournaise), cliffs or "ramparts", deep gorges and waterfalls which, together with endemic flora and fauna, helped the central part of La Réunion to be recently recognised by UNESCO as a World Heritage Site. Yet, induced natural hazards such as volcanic eruptions and landslides remain a threat for the population.
\end{abstract}

\section{Keywords}

Basaltic shield volcanoes $\bullet$ Volcanic geomorphology $\bullet$ Evolution $\bullet$ Natural hazard

\subsection{Geographical and Geological Setting}

La Réunion Island (Fig. 25.1a, b), located in the western Indian Ocean $\left(21^{\circ}\right.$ south and $55^{\circ}$ east $)$, has a subaerial extent of around $2,500 \mathrm{~km}^{2}$, composing an elliptic island shape $(60 \mathrm{~km} \times 70 \mathrm{~km})$ elongated along a N120 $0^{\circ}$ axis. The island is a volcanic complex composed of at least three edifices. Two of them are currently visible in the landscape (the Piton des

\section{N. Villeneuve $(\bowtie)$}

Laboratoire Géosciences Réunion, Université de La Réunion, Institut de Physique du Globe de Paris, Sorbonne Paris-Cité, UMR 7154 CNRS, 97715 Saint-Denis, France

e-mail: nicolas.villeneuve@univ-reunion.fr

\section{P. Bachèlery}

Laboratoire Magmas et Volcans, UMR 6524, CNRS-IRD-

Université Blaise Pascal, Observatoire de Physique du Globe de Clermont-Ferrand, 5 rue Kessler, 63038 Clermont-Ferrand, France e-mail: P.Bachelery@opgc.fr

\section{J. Kemp}

Department of Geography and Environmental Studies, Stellenbosch University, Private Bag X1,

Matieland 7602, South Africa

e-mail: jkemp@sun.ac.za
Neiges, 3,070 m, and the Piton de la Fournaise, 2,632 m), and the third one, called Les Alizés volcano, considered to have grown before about $600 \mathrm{Ka}$, is now completely dismantled (Lénat et al. 2012) by large mass-wasting events (Le Friant et al. 2011; Oehler et al. 2008) and erosion (Saint-Ange et al. 2011; Salvany et al. 2012).

The Piton des Neiges volcano, located on the northwestern part of the island, is inactive since $12 \mathrm{Ka}$ (Deniel et al. 1992). It is currently accepted that the Piton des Neiges built up in four main stages. The Piton de la Fournaise, on the southeastern part, is considered one of the most active volcanoes in the world with an average of 0.8 eruptions per year since 1998 .

La Réunion is situated in the tropics, just north of the Tropic of Capricorn. This intertropical, oceanic setting gives the island a humid tropical climate, with an annual average humidity of between 70 and $80 \%$. Two main seasons can be distinguished: the southern winter and the southern summer, with winter bringing polar air closer to the island resulting in lowered temperatures.

During the summer months, specifically January to March, La Réunion is strongly affected by tropical depressions and cyclones. These systems sweep over La Réunion with 


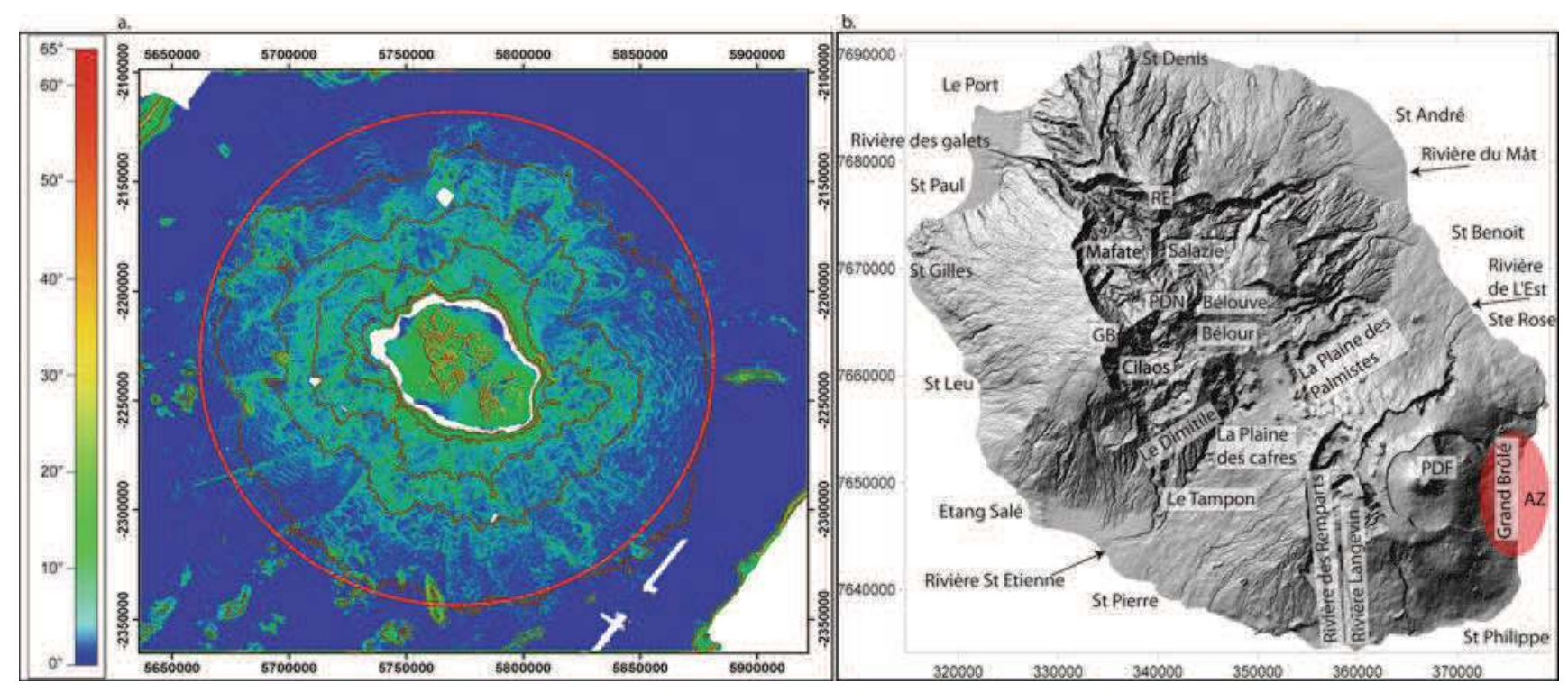

Fig.25.1 (a) Slope gradient computed from FOREVER and ERODER swath bathymetry and IGN DEM (1997) for the aerial part. Brown lines corresponded to $-4,000,-3,000,-2,000-1,000$ and $-500 \mathrm{~m}$ isobath. The red circle shows the approximate boundary between La Réunion and the abyssal plain. (b) Shaded relief map of Réunion Island showing

wind speeds that can reach $250 \mathrm{~km} / \mathrm{h}$ and release enormous amounts of precipitation onto the island. In fact, La Réunion holds several world records for precipitation, being the place where the highest rainfalls for periods between $1 \mathrm{~h}$ (261.5 mm on 29 February 1964, Cyclone Giselle) and 15 days (6,083 $\mathrm{mm}$ between 14 and 28 January 1980, Cyclone Hyacinthe) have been recorded. Globally, cyclones are very well studied, followed and known. Nevertheless, in terms of risk on La Réunion, they are the most significant factor responsible for deaths and injuries. They are also responsible for much damage to the infrastructure on which the community and local economy relies.

Outside the cyclone period, precipitation is highly variable in both time and space. The rainfall distribution on La Réunion is most strongly influenced by its topography. In winter, the southeasterly trade winds (known locally as Alizés) carry humid air to higher elevations, causing adiabatic cooling and precipitation on the eastern mountain slopes. Mean annual precipitation for La Réunion ranges from around $750 \mathrm{~mm}$ on the sheltered west coast to more than $10,000 \mathrm{~mm}$ on the slopes of Piton de la Fournaise in the east (Fig. 25.2).

These significant quantities of rainfall had dramatic implications for soil erosion and sediment transport by the island's rivers. With La Réunion's high rainfall, steep slopes and young reliefs, rates of erosion and sediment transport are huge and often considered some of the highest in the world (Garcin et al. 2005). the location of Piton des Neiges (PDN), Piton de la Fournaise (PDF) volcanoes and place names. The red oval (AZ) corresponds to the hypovolcanic complex Les Alizés volcano as defined by Salvany et al. (2012). Read Roche Ecrite and Grand Bénare for RE and GB. Coordinates in metres (WGS84, UTM40S)

\subsection{Gross Morphology of La Réunion Complex}

Around La Réunion Island, large amounts of debris avalanche deposits and numerous secondary submarine slope instabilities, resulting from the sliding and spreading of the submarine volcano flanks, have been recognised (Oehler et al. 2008; Le Friant et al. 2011).

Several authors have proposed different interpretations of morphologies of La Réunion's bathymetry linked directly to onshore geological processes. Recently, high-resolution bathymetric acquisition during the FOREVER and ERODER cruises allowed very fine scale analyses and models that complement those of Oehler et al. (2008).

La Réunion, from the abyssal plain to the summit of the Piton des Neiges volcano, is a large $7 \mathrm{~km}$ high cone (Fig. 25.1a) with a total volume of about $5.01 \cdot 10^{4} \mathrm{~km}^{3}$. Considering that the subaerial part has a volume of $2.1 \cdot 10^{3} \mathrm{~km}^{3}$, only $4 \%$ of the volcanic complex is above sea level. The contact between La Réunion Island's volcanic products and the abyssal plain can be considered to lie at an average depth of 4,200 m.

The La Réunion Island volcanic complex is relatively well contained within a circle (radius $80-100 \mathrm{~km}$ ) centred on the Piton des Neiges present summit (red circle, Fig. 25.1a). This mainly corresponds to the slope transition between the abyssal plain and the cone of the volcanic complex, and Le Friant et al. (2011) explained the stretching towards the southeast as a consequence of a series of massive debris 


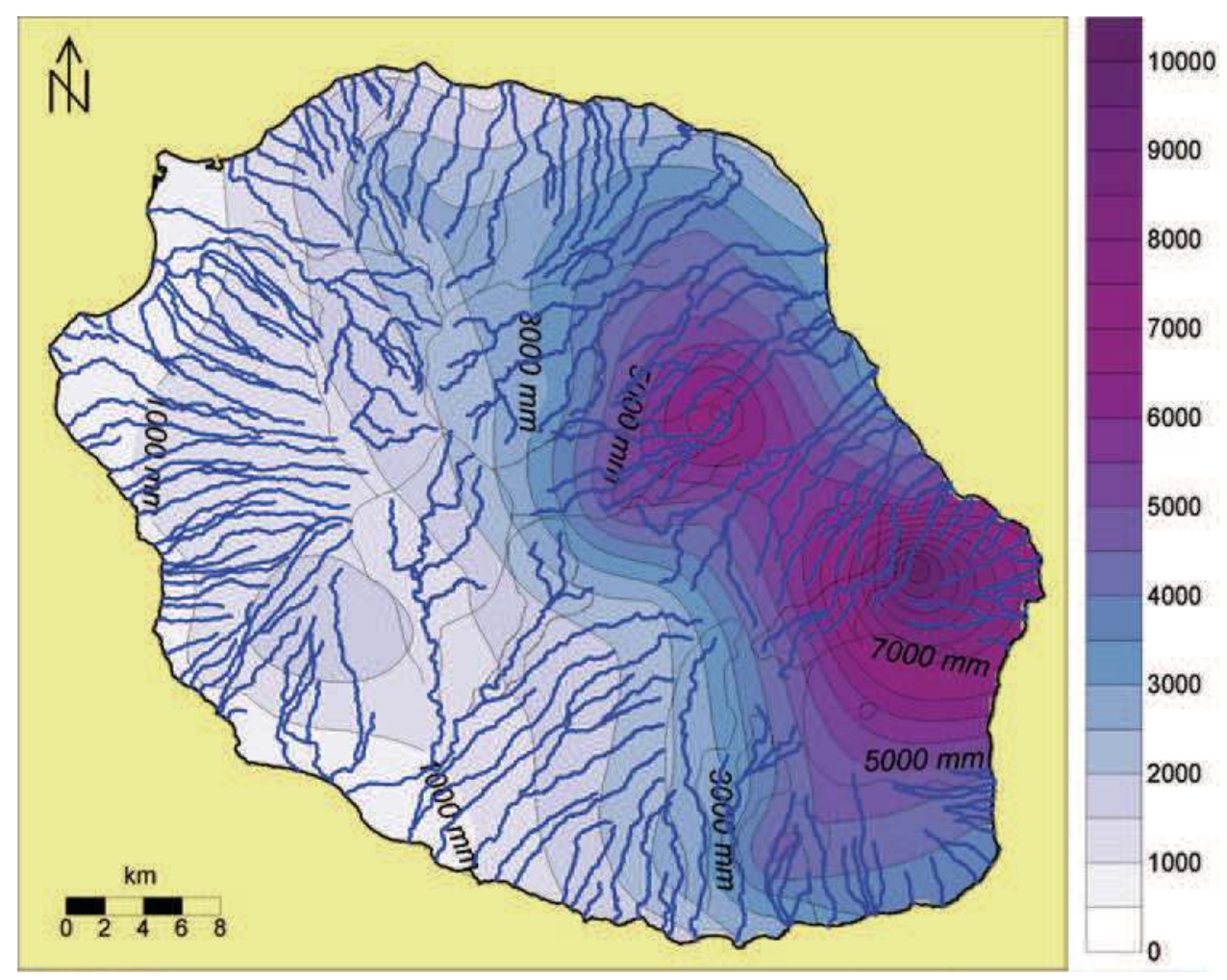

Fig. 25.2 Mean annual precipitation (between 1971 and 2000) overlain by the hydrologic network for La Réunion. Isohyets have a contours spacing of $500 \mathrm{~mm}$ (Data from Meteo-France)

avalanches that occurred at Piton de la Fournaise (red oval, Fig. 25.1b). These authors mainly proposed that flank destabilisation, onshore and offshore, would be less massive on Piton des Neiges than on Piton de la Fournaise.

\subsection{Geomorphic Landscape of the Volcanic Island}

\subsubsection{A Very Rapid Evolution}

La Réunion Island is characterised by a rapid landscape evolution resulting from a favourable geology combined with a tropical climate. Relationships between dramatic climatic events, small-scale and large-scale landslides, torrential transport of sediments and active volcanism lead to rapid evolution in terms of building, dismantling and/or refilling of recently formed geomorphic features.

The most remarkable example occurred during the large 2007 eruption of the Piton de la Fournaise when the centre of Cratère Dolomieu dropped $350 \mathrm{~m}$ in height in only a few hours (Fig. 25.3a, b) without significantly modifying the crater contour (Fig. 25.3c). Conversely, paleo-valleys on La Réunion have been infilled by new lava flows, as can be observed in the upper reaches of the Rivière des Remparts (Fig. 25.4).
The coexistence of contrasted (building $v s$ dismantling) and rapid evolution of the landforms in the same area, as highlighted by these two examples, certainly is one of the most interesting features of geomorphology concerning very active volcanoes.

Unstable cliffs and slopes are often sites of mass wasting such as collapses and debris avalanches, responsible for large to massive scale landforms like Cirques. The most massive landslide is the Saint-Gilles slide on the western flank of Piton des Neiges (Bachèlery et al. 2003). The various breccia units cover an area of $16 \mathrm{~km}^{2}$. Bathymetric surveys show the offshore prolongation of "Saint-Gilles breccias" up to a depth of 2,500 m, allowing us to estimate the total area covered by the debris avalanche deposits at more than $500 \mathrm{~km}^{2}$.

The main river systems on La Réunion also drain the edifices of Piton des Neiges and Piton de la Fournaise in a generally radial pattern. Applying the Ollier (1988) model to La Réunion, Piton de la Fournaise would be in the intact stage, while Piton des Neiges would be in the planeze stage.

\subsubsection{Main Geomorphological Features of the Piton des Neiges Volcano}

In terms of emerged surface extent, the Piton des Neiges volcano represents two-thirds of the total island area. At the 

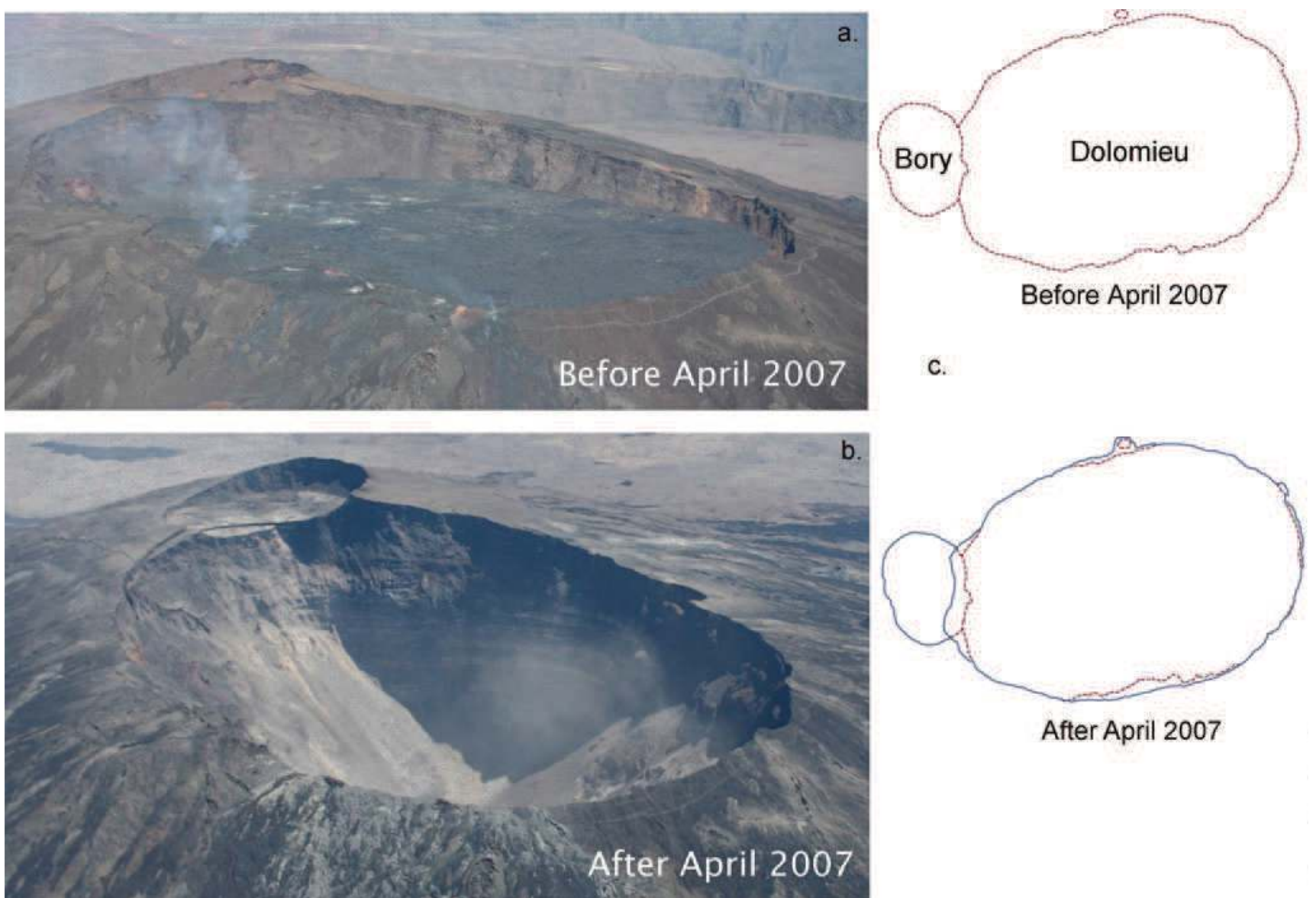

After April 2007

Fig. 25.3 Southeastern aerial photos of the Piton de la Fournaise summit before (a) and after (b) the collapse in April 2007. The mapping of the Dolomieu (foreground) and Bory (background) crater outlines from orthophotos acquired in 2003 and 2007 illustrates the relatively small change to Piton de la Fournaise in plan view compared to the extent of the vertical collapse (c) core of Piton des Neiges, three large depressions (locally known as "Cirques") exist, namely, the Cirque de Salazie drained by Rivière du Mât to the northeast, the Cirque de Cilaos drained by Rivière St-Etienne to the south and the Cirque de Mafate drained by Rivière des Galets to the northwest (Figs. 25.1b and 25.2). They are the main and the most spectacular features of the Piton des Neiges edifice.

The origin of these major depressions has been widely discussed. Several authors have assumed either a volcanotectonic or erosional origin, sometimes associated with massive debris avalanches. Oehler et al. (2008) proposed a multi-process origin, combining erosion, structural events and massive landslides. Except for the high cliffs surrounding the Cirques and some other rare reliefs inside, breccia deposits largely blanket the bottom of the three Cirques. It is quite difficult to recognise the source of the breccias and to distinguish between an erosional or tectonic origin for the landscape. The two processes were certainly acting together for millennia to build this spectacular relief. Currently, weathering can efficiently proceed on breccia materials that compose the cirque floor, and the debris inside is very easily mobilised, supplying a strong transport of sediment off the island.

As already said, Piton des Neiges built up in four main stages. Salvany et al. (2012) assumed that the Cirques began to form with the lowering of the lava output rate of Piton des Neiges, around $180 \mathrm{Ka}$ ago (Phase I). Around 12,000 years ago (Deniel et al. 1992), all magma production on Piton des Neiges stopped, and only erosive mechanisms remained, which widened and deepened the Cirques to their current state, accounting for negative volumes of more than $101 \pm 44$ and $105 \pm 41 \mathrm{~km}^{3}$ for the Mafate and Cilaos Cirques. For Salazie cirque, Salvany et al. (2012) considered that it had been filled by lava $70 \mathrm{Ka}$ ago. The same erosional volume has been obtained in only $70 \mathrm{Ka}$.

The external slopes of Piton des Neiges volcano are less dismantled. With an almost triangular shape dissected by three rivers, they form large Planezes, stretching from Le Grand Bénare to the western coastline for the Western Planeze, from la Roche Ecrite to the northern coastline for the Northern Planeze and from the Piton des Neiges to the eastern coastline and to the Plaines area for the Eastern Planeze. 

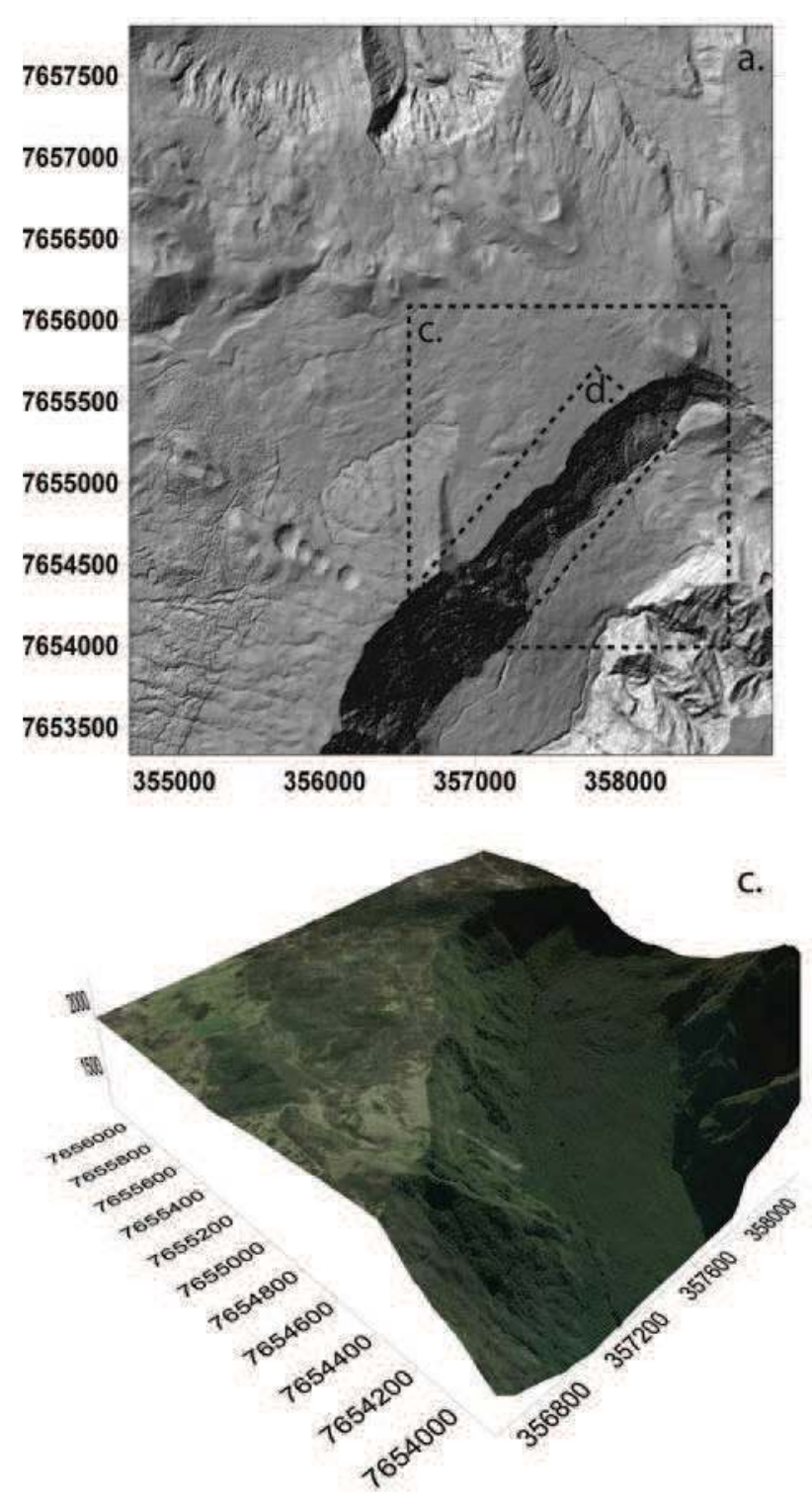

Fig. 25.4 Infilling of a paleo-Rivière des Remparts on the northeastern side of Rivière des Remparts. (a) Shaded relief of $5 \mathrm{~m}$ DEM (IGN); (b) slope gradient computed from the $5 \mathrm{~m}$ DEM, 1 and 2 on the north Rivière des

The Western Planeze, largely covered by recent lavas (Phase IV), is particularly smooth (Figs. 25.1 and 25.5). This is the result of both recent refilling of erosion morphologies by lava flows and of its relative protection against weathering. For the Northern Planeze, the La Montagne edifice is much more eroded. This area has not been overflowed by Phase III (partially) and Phase IV of the Piton des Neiges lava flows (Fig. 25.5). This signifies that soils have been eroded during a long period estimated at least to $450 \mathrm{Ka}$.

The Le Dimitile edifice and patchwork on the Eastern Planeze have the same configuration. This Planeze is very complex. First, its southeastern extent is limited by the Piton
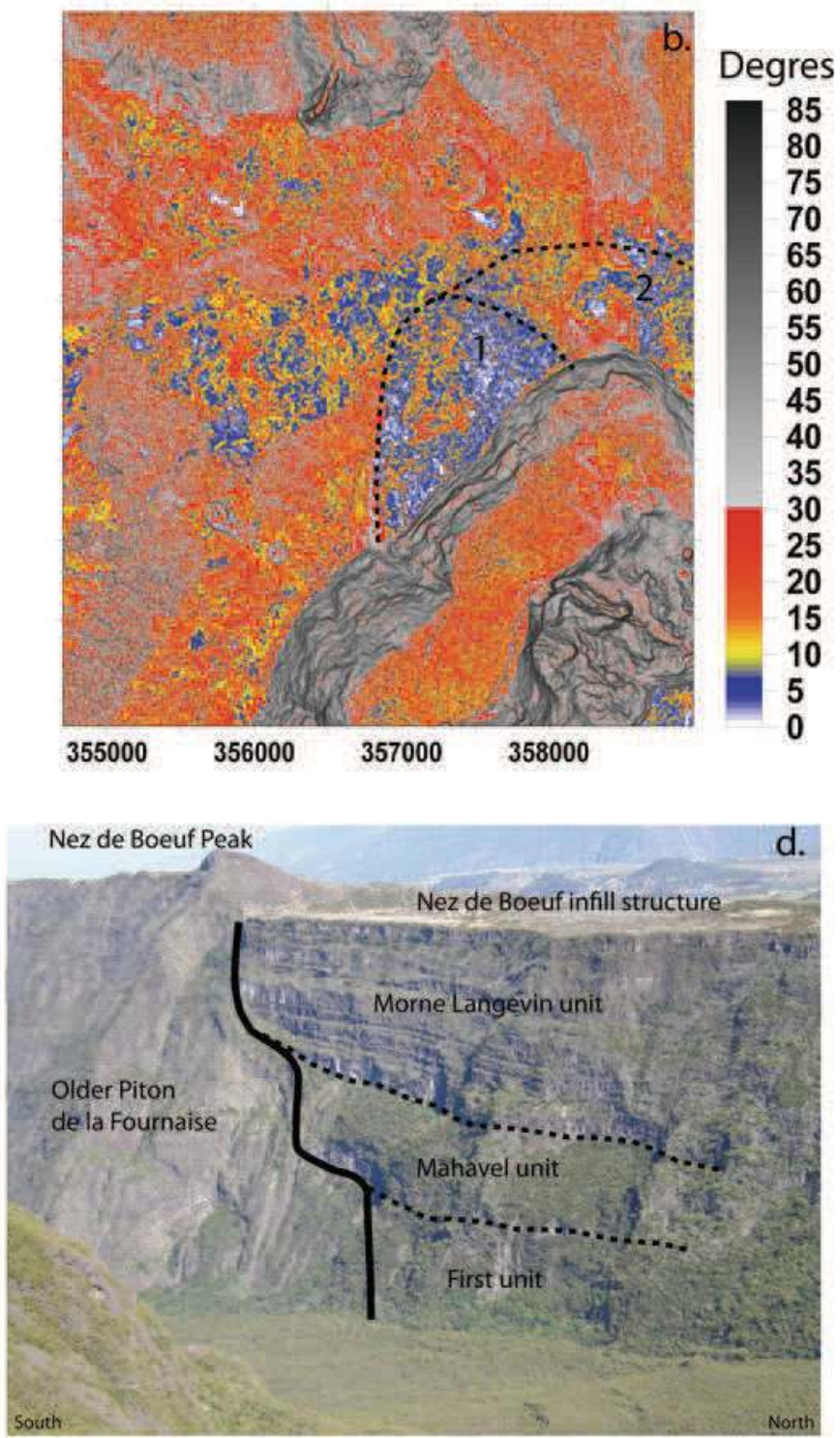

Remparts head correspond to the possible extension of the river before infilling; (c) a 3D surface (2012 orthophoto from IGN); (d) outcrop view from east (From Merle et al. 2010)

de la Fournaise formations. Secondly, the Bebour-Belouve area is a deep depression that is considered a paleo-cirque infilled with recent lava flows.

\subsection{Main Geomorphological Features of the Piton de la Fournaise Volcano}

Piton de la Fournaise is composed of at least four different landscapes (Figs. 25.6 and 25.7): the Enclos Fouqué and Grand Brûlé structures, the northeast and southeast rift zones, the main rivers scars and the Saint Pierre-Les PlainesSaint Benoit corridor. 

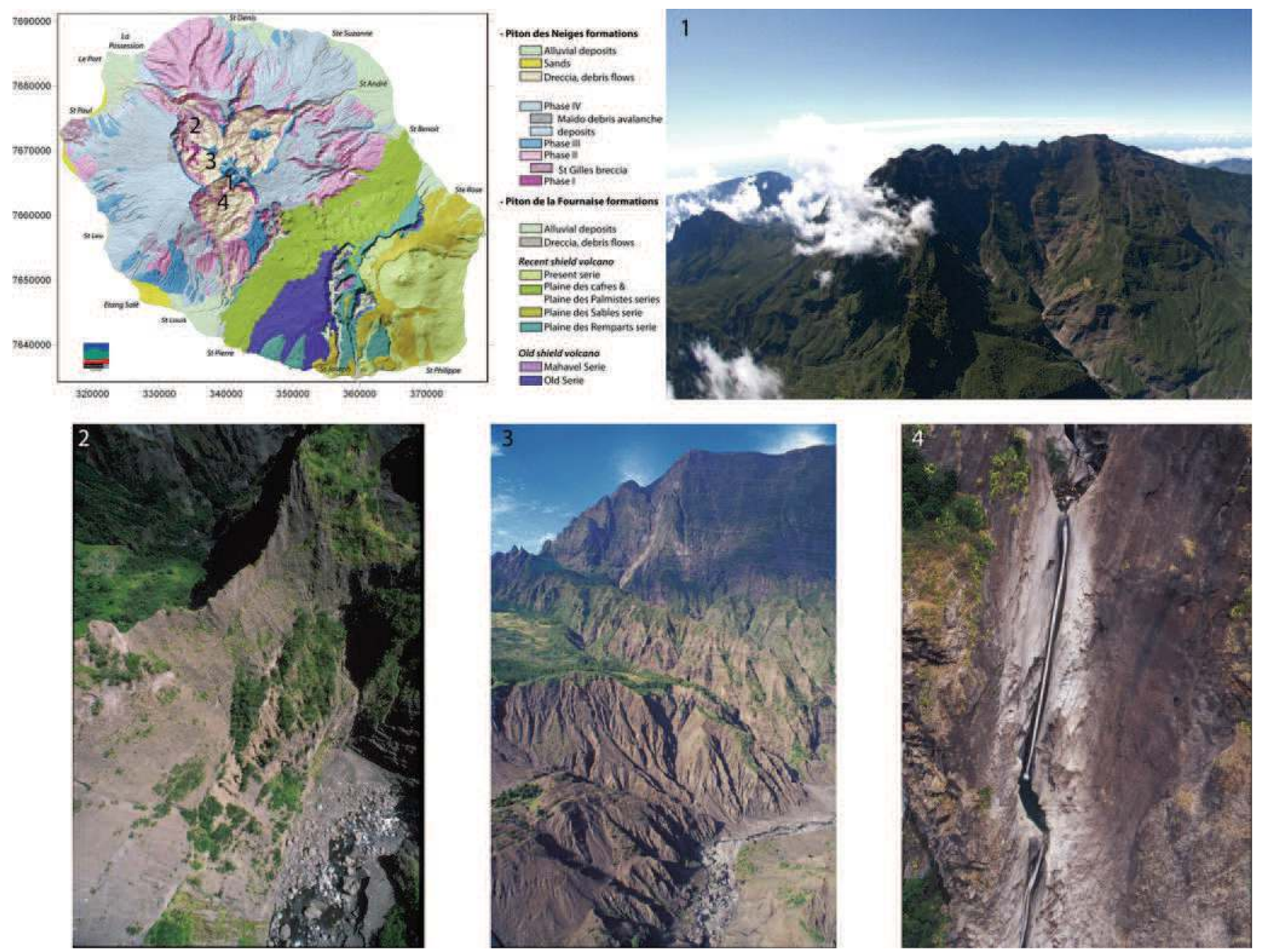

Fig. 25.5 Geological map of La Réunion (From Fèvre 2005). Photos: Eroded landscapes in the Cirques. 1 Old, eroded Piton des Neiges, aerial view from the west; 2 very narrow crest formed by collapse of unstable materials in Mafate; 3 Badlands developed in unstable materials in Mafate; 4 the huge "Fleur Jaune" waterfall dropping from massive materials in Cilaos

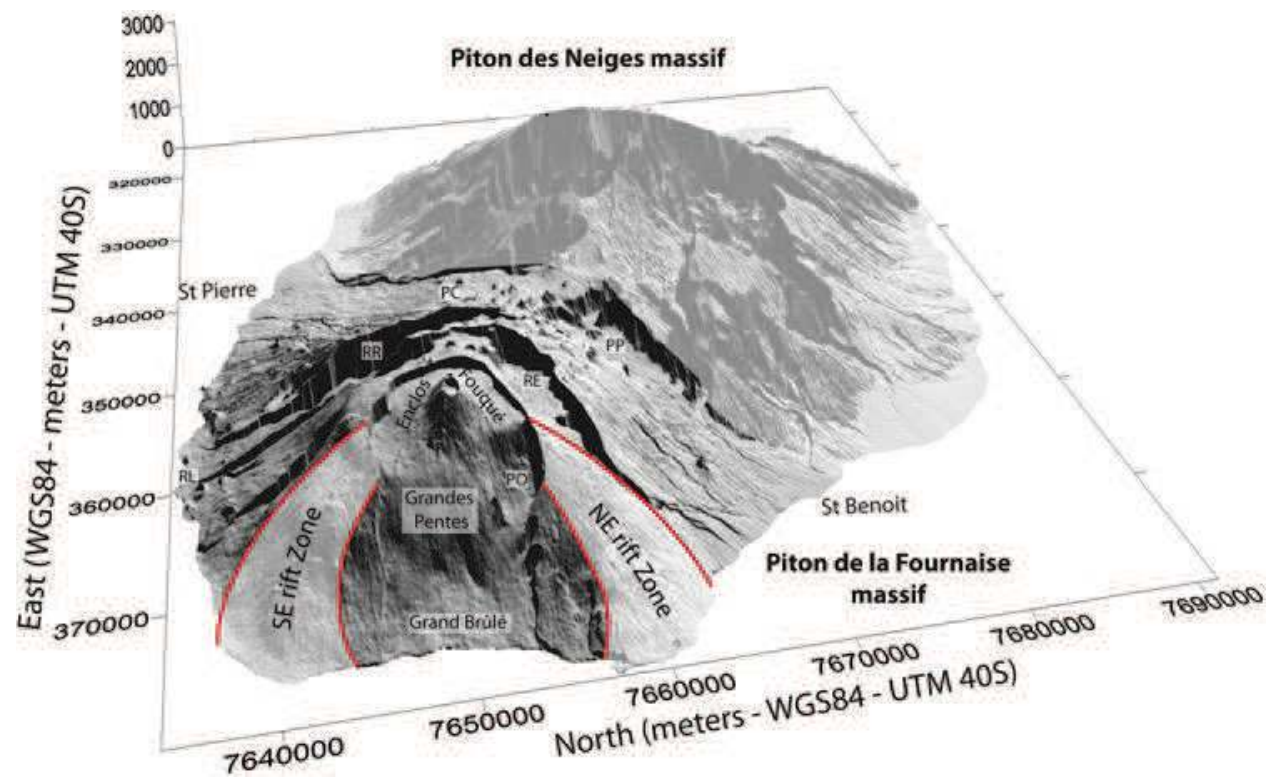

Fig. 25.6 Eastern view of Piton de la Fournaise volcano (25 m DEM from IGN). Read Rivière de l'Est for RE; Rivière des Remparts for RR; Rivière Langevin for RL; Plaines des Cafres for PC; Plaine des Palmistes for PP; Plaine des Osmondes for PO 

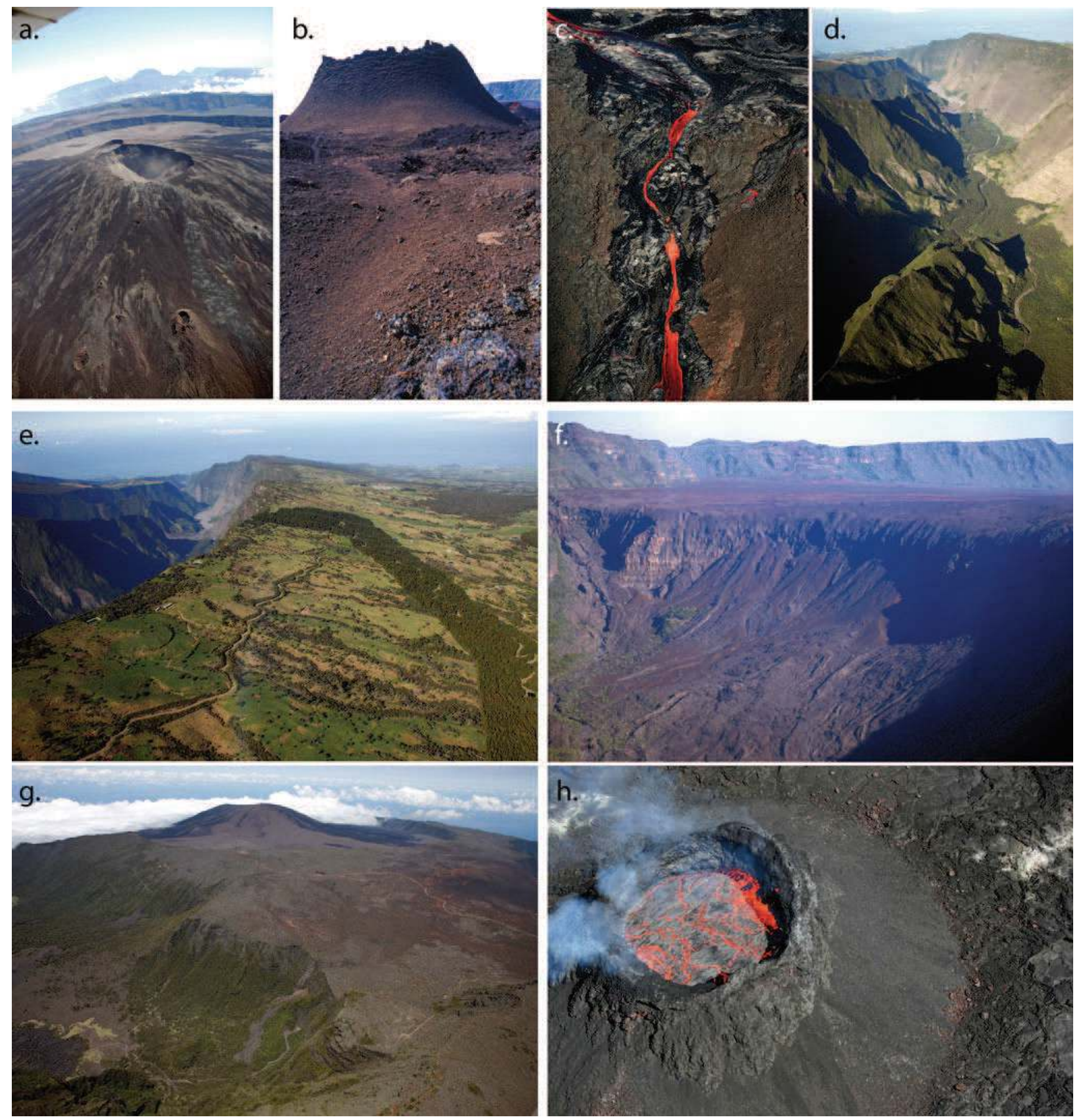

Fig. 25.7 Synthesis of different morphologies observable on the Piton de la Fournaise edifice. (a) Summit of the Piton de la Fournaise with the Cratère Dolomieu and the Cratère Bory; (b) Château Fort crater vent: a very typical scoriaceous cone shape; (c) pahoehoe lava flow overlapping an "aa" lava during the August 2006 event; (d) Rivière des Remparts

viewed from north; (e) Plaine des Cafres and Rivière des Remparts (left); (f) lava flows from the Chisny eruption which had entered Rivière Langevin $1 \mathrm{Ka} ;(\mathbf{g})$ upper catchment of Rivière de l'Est called Savane Cimetière, viewed from north; (h) a lava lake enclosed within a scoriaceous cone during the August 2006 eruption

\subsubsection{The Enclos Fouqué and Grand Brûlé}

This is a large uninhabited horseshoe structure of $\sim 100 \mathrm{~km}^{2}$, open to sea on the eastern part of the island. Four main morphological units can be observed: (1) the summit area,

(2) the "Remparts", (3) the Grandes Pentes and the Plaine des Osmondes and (4) the Grand Brûlé. The main geomorphological features of the Enclos Fouqué are related to the volcanic and tectonic histories of the area associated with recent events. Presumably, the formations have been shaped 
by a series of events whose initial process is a combination of structural instabilities and local collapses linked with phreatomagmatic and phreatic explosions that could be paroxysmal. Morphologies are also linked to lava infilling and smoothing.

Bory $(250 \mathrm{~m} \times 350 \mathrm{~m})$ and Dolomieu $(750 \mathrm{~m} \times 1,100 \mathrm{~m})$ craters constitute the summit part of Piton de la Fournaise, as viewed from the west, where they top a $400 \mathrm{~m}$ high central cone. These landforms owe their origin to repeated collapses; though relatively rare, these collapse events usually occur in relation with high lava effusion rates. Michon et al. (in press) describe 14 events between 1791 and April 2007. Ten of these events are responsible for phreatic and/or phreatomagmatic activities. These events generate a real risk for summit hikers ( 120,000/year) and Pas de Bellecombe visitors ( 270,000/year). In April 2007, a $\sim 90 \cdot 10^{6} \mathrm{~m}^{3}$ caldera completely modified the geometry inside the Cratère Dolomieu (Fig. 25.3a, b).

The two summit craters are surrounded by high slopes with an average gradient of between $15^{\circ}$ and $25^{\circ}$. They are relatively constant in all directions for $1.6 \mathrm{~km}$ from the centre of the Cratère Dolomieu. Several small eruptive vents are visible on the slope of the terminal cone. Between 30 and 50 cones per square kilometre can be counted in this area.

The western part of the Enclos Fouqué is relatively flat. Lénat et al. (2001) named this area the "Champ de Lave de l'Enclos Fouqué". Pahoehoe lava mainly composes this large lava field and is probably related to the late activity of the Cratère Bory during the seventeenth and eighteenth centuries.

The Enclos Fouqué/Grand Brûlé area is edged by $\sim 35 \mathrm{~km}$ of cliffs, namely, the "Remparts". These are 100-200 m high subvertical cliffs. They are natural barriers that protected inhabited areas against lava flows coming from more frequent eruptions.

The Grandes Pentes correspond to $\sim 25 \%$ of the total area of the horseshoe depression. Here, the slope gradients range between $25^{\circ}$ and $30^{\circ}$. Their formation is probably linked to landslides and/or spreading of the volcanic edifice.

The Plaine des Osmondes, localised northeast of the central cone, is a depressed area $(2.5 \times 4 \mathrm{~km})$, edged on the north, the west and the south by the "Remparts", the Grandes Pentes and Le Piton de Crac, respectively. The eastern part opens this area towards the Grand Brûlé. Courteaud (1996), from geophysical data, has interpreted the Plaine des Osmondes as the head of paleo-valley that could have been built during a long period of quiescence of the volcano, at least in this region.

The Grand Brûle is a relatively flat $\left(4^{\circ}\right.$ to $\left.8^{\circ}\right)$ corridor between the Grandes Pentes and the coast. Its morphology is probably related to lava accumulation. Below the sea level, the Grand Brûlé stretches into the Chenal Vincent unit (Oehler et al. 2008). From Michon et al. (submitted), lava flows of about 28 eruptions have crossed the Grand Brûlé and reached the ocean since the beginning of the sixteenth century. The emplacement of lava flows crossing the coastal road (used daily by about 3,200 vehicles) and reaching the seashore occurs relatively often. Lava flows entering the sea are very impressive. Nevertheless, the difference in temperature generates explosions on the unstable platform built up by the progression of the lava flow, and acid plumes generated by seawater vaporisation can cause respiratory problems and/or environmental damage.

\subsubsection{The Northeast and Southeast Rift Zones}

Both rift zones are convex surfaces that stretch along steep slopes (Fig. 25.6). This morphology has been mapped below sea level up to depths of 1,800 and 2,000 $\mathrm{m}$ for the southern and northern zones, respectively. The rift zones correspond to areas of preferential magma ingestion for the volcano summit towards the outside flanks. Between 1708 and 1998, seven eruptions (three on the northeast and four on the southeast rift zones) occurred in these areas. Their implication in terms of volcanologic risk is important. For instance, in 2012, 11,809 permanent residents lived in areas located within these rift zones.

\subsubsection{The Main River Scars}

On Piton de la Fournaise, 19 drainage basins have been identified, but only Rivière de l'Est, Rivière Langevin and Rivière des Remparts have perennial flow. All three rivers are fed by springs resulting from rapid infiltration due to the high permeability of the rocks and the high rainfall.

Four main hydrologic units are well identifiable on the Piton de la Fournaise edifice. Rivière de l'Est $\left(24.5 \mathrm{~km}^{2}\right)$ is the only one cut into the north flank of the volcano. The Ravine Basse Vallée $\left(9 \mathrm{~km}^{2}\right)$, the Rivière Langevin $\left(23 \mathrm{~km}^{2}\right)$ and the Rivière des Remparts $\left(56 \mathrm{~km}^{2}\right)$ drain the southern flank of the volcano. They are affected by different geomorphic processes (collapses and topographic inversion).

Erosion is clearly the main process involved in their formations, but a more complex history, with caldera and mass-wasting episodes, has been revealed by a detailed study of Rivière des Remparts and Rivière Langevin (Merle et al. 2010). Rockfalls and landslides are common in these valleys. They result from (1) differential resistance of materials, (2) regressive erosion mechanisms and (3) hydrogeological erosion mechanisms as described by Fèvre (2005). In addition, several lava flows may also locally cover the riverbeds, showing that volcanic activity may continue after the erosion of the river. 


\subsubsection{The Saint Pierre-Les Plaines-Saint Benoit corridor}

The Saint Pierre-Les Plaines-Saint Benoit corridor is a smooth surface that has been covered by relatively recent lava flows. These areas compose the morphological transition between the Piton de la Fournaise and Piton des Neiges volcanoes. The Plaine des Palmistes is the most complex area. It is a depression open to the sea, and its northern, western and southern cliff slopes are steep. The current morphology of this area certainly reveals the preponderance of erosional mechanisms.

\subsection{Main Geomorphological Features of Coastlines}

La Réunion Island is composed of $250 \mathrm{~km}$ of coastline that can be classified into three main groups (Fig. 25.8):

- $140 \mathrm{~km}$ of volcanic coastline
- $85 \mathrm{~km}$ of alluvial coastline

- $25 \mathrm{~km}$ of coral sand coastline

The volcanic coastlines can be divided into two types: (1) low volcanic platforms and (2) volcanic cliff shorelines that can be also called wave-straightened cliffs in volcanic areas. The first type has its origin in lava flows entering into the sea and can also be residual platforms. The second type develops under wave action at the bottom of cliffs that generates instabilities, such as rockfalls and landslides. From Grand Bois to Sainte Rose, on Piton de la Fournaise, the coastline is composed of $65 \mathrm{~km}$ of uninterrupted, generally high volcanic cliffs. The possible cliff collapses are a threat for the population. On Piton des Neiges, along "La Corniche" which is the highest and longest coastal cliff ( 13 km long and 100-200 m high) and along the Cap La Houssaye cliff, very high-traffic roads have been built at the foot of both cliffs. Several collapses have occurred, causing dramatic accidents, making these roads the most hazardous and at-risk areas.

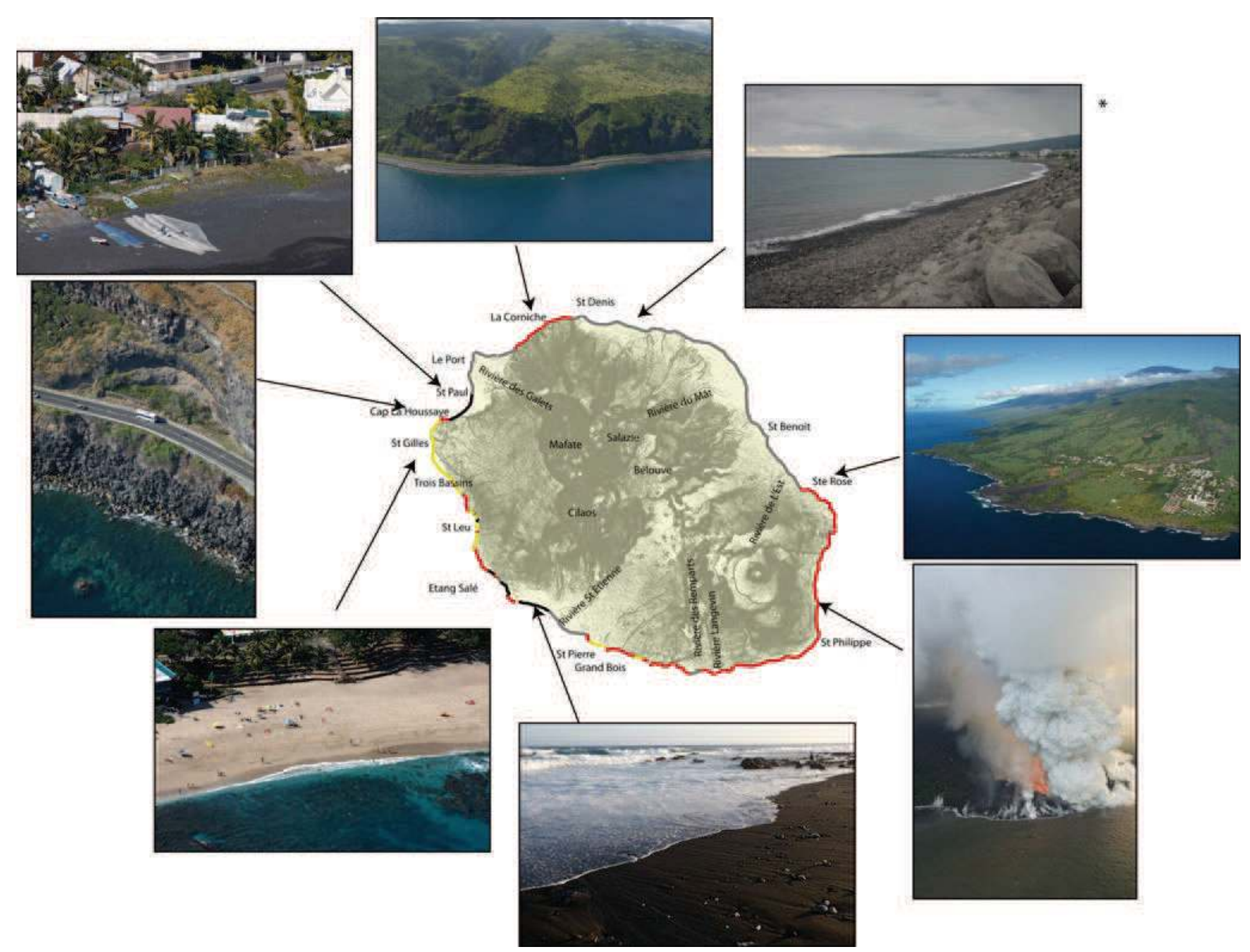

Fig. 25.8 Synthesis of different coastal morphologies observable around La Réunion. Coastline colour code: red for volcanic cliff, yellow for coral sand beaches, black for black sand beaches and grey for rolling stone beaches (*Courtesy of Olivier David) 
The alluvial coastlines include two types - (1) the black sand beaches and (2) the rolling stone beaches - directly linked to the transfer of fluvial erosion products and grainsize sorting. Along the eastern coast (from Sainte Rose to Saint Denis), the $51 \mathrm{~km}$ long beach of rolling stones formed after hydraulic processes have washed away fine sediments. The same process occurred in small river deltas around La Réunion. In contrast, the Saint Paul and Etang Salé black sand beaches are mostly composed of fine sediments transported by marine currents. Here, strong winds have also transported fine particles to develop black sand dunes. In the Grand Brûlé area, two black sand beaches developed under a specific process: when the lava flows reached the sea, the contrast of temperature produced explosions generating volcaniclastic materials. The accumulation of these products usually builds non-permanent beaches.

The coral sand beaches are localised (1) from the south of Cap La Houssaye to La Souris Chaude in the Saint-Gilles area, (2) from La Pointe des Chateaux to La Pointe au Sel in the Saint Leu area, (3) from Ravine Blanche to Terre Sainte in the Saint Pierre area and (4) in the Grand Bois area. These have been built recently, less than 8,000 years ago (Camoin et al. 1997), by accumulation of the biodetritic elements from the reefs. The Saint-Gilles units are the largest ones. Around 12 linear kilometres are composed by the sand beach (160 m wide at its maximum), and sand dune accumulation is limited by old volcanic cliffs. The accumulation of sand can reach a maximum of $200 \mathrm{~m}$ in thickness.

\subsection{Conclusion, Cultural Value and Touristic Promotion}

Lava flows, landslides, floods and rockfalls have built La Réunion Island with its incredibly diverse landscapes. The high cliffs, steep valleys and variety of microclimates have allowed 236 endemic plant species and 92 endemic animal species (23 of which are extinct and 4 of which are threatened) to grow locally. For these reasons, $40 \%$ of La Réunion Island is included in the UNESCO Nature World Heritage list. This international label covers the core of the National Park of La Réunion. This is not only a source of pride for residents but a true added value for the touristic promotion and the environment protection.

The great paradox is that the magnificent morphologies and areas celebrated here are also those for which natural hazard and risk are the highest.

\section{References}

Bachèlery P, Robineau B, Courteaud M, Savin C (2003) Avalanches de débris sur le flanc occidental du volcan-bouclier Piton des Neiges (Réunion). Bull Soc Géol Fr 174:125-140

Camoin GF, Colonna M, Montaggioni LF, Casanova J, Faure G, Thomassin BA (1997) Holocene sea level changes and reef development in southwestern Indian Ocean. Coral Reef 16: 247-259

Courteaud M (1996) Etudes des structures géologiques et hydrogéologiques du massif de La Fournaise par la méthode audiomagnétollurique. $\mathrm{PhD}$ thesis, Université de La Réunion, Réunion, p 212

Deniel C, Kieffer G, Lecointre J (1992) New 230Th-238U and 14C age determinations from Piton des Neiges volcano, Reunion - a revised chronology for the differentiated series. J Volcanol Geotherm Res 51:253-267

Fèvre Y (2005) Mécanismes et vitesses deérosion à l'échelle géologique sur une île volcanique jeune à relief élevé - La Réunion (Océan Indien). PhD thesis, Université de La Réunion, p 217

Garcin M, Poisson B, Pouget R (2005) High rates of geomorphological processes in a tropical area: the Remparts River case study (Réunion Island, Indian Ocean). Geomorphology 67(3):335-350. doi:10.1016/j.geomorph.2004.11.002

Le Friant A, Lebas E, Clément V, Boudon G, Deplus C, De Voogd B, Bachèlery P (2011) A new model for the evolution of La Réunion volcanic complex from complete marine geophysical surveys. Geophys Res Lett 38:L09312. doi:10.1029/2011GL047489

Lénat J-F, Bachèlery P, Desmulier F (2001) Genèse du champ de lave de l'Enclos Fouqué: une eruption d'envergure exceptionnelle au Piton de la Fournaise (Réunion) au 18ème siècle. Bull Soc Géol Fr 172:177-188

Lénat J-F, Bachèlery P, Merle O (2012) Anatomy of Piton de la Fournaise volcano (La Réunion, Indian Ocean). Bull Volcanol 74:1945-1961. doi:10.1007/s00445-012-0640-y

Merle O, Mairine P, Michon L, Bachèlery P, Smietana M (2010) Calderas, landslides and paleo-canyons on Piton de la Fournaise volcano (La Réunion Island, Indian Ocean). J Volcanol Geotherm Res 189:131-142

Michon L, Di Muro A, Villeneuve N, Saint-Marc C, Fadda P, Manta F (in Press) Explosive activity of the summit cone of Piton de la Fournaise volcano (La Réunion island): a historical and geological review. Submitted to J Volcanol Geotherm Res

Oehler J-F, Lénat J-F, Labazuy P (2008) Growth and collapse of the Reunion Island volcanoes. Bull Volcanol 70:717-742. doi:10.1007/ s00445-007-0163-0

Ollier C (1988) Volcanoes. Blackwell, Oxford

Saint-Ange F, Savoye B, Michon L, Bachèlery P, Deplus C, De Voogd B, Dyment J, Le Drezen E, Voisset M, Le Friant A, Boudon G (2011) A volcaniclastic deep-sea fan off La Réunion Island (Indian Ocean). Grad Vs Catastr Geol 39:271-274. doi:10.1130/ G31478.1

Salvany T, Lahitte P, Nativel P, Gillot P-Y (2012) Geomorphic evolution of the Piton des Neiges volcano (Réunion Island, Indian Ocean): competition between volcanic construction and erosion since 1.4 Ma. Geomorphology 136:132-147. doi:10.1016/j. geomorph.2011.06.009 